\title{
Buccal manifestations in diabetic patients with complete dentures
}

\begin{abstract}
The objective of this work is to perform a literature review on the association between Diabetes Mellitus and oral manifestations in users of total prosthesis. The included databases were BBO, LILACS, PubMed, Scielo and the oral manifestations that were mostly present were: Xerostomia, Prosthetic Stomatitis, and Candidiasis. It was found that in the reviewed articles, there was a greater susceptibility among diabetic patients to have such manifestations. However, a well manufactured and adapted prosthesis together with good oral hygiene, as well as an adequate control of the chronic disease are determinant so as not to aggravate these conditions. Nevertheless, further randomized and controlled trials are needed to provide more conclusive answers on oral manifestations in diabetic users of total prosthesis.
\end{abstract}

Keywords: diabetes mellitus, total prosthesis, oral manifestation
Volume 4 Issue I - 2019

\author{
Vanessa Burriél de Araújo, Cássio do Carmo \\ Machado, Tatiane Gonçalves Duque, Tânia PS \\ Lacerda \\ Associate Professor of Dentistry, Universidade Cidade de São \\ Paulo, Brazil
}

\begin{abstract}
Correspondence: Tânia e SP Lacerda,Associate Professor of Dentistry, Universidade Cidade de São Paulo and São Leopoldo Mandic Graduate Center, Brazil, Email tanialacerda@col.odo.br
\end{abstract}

Received: December 20, 2018 | Published: January 08, 2019

\section{Introduction}

Diabetes Mellitus encompasses a group of metabolic disorders that can lead to hyperglycemia. The main symptoms are polydipsia, polyuria, polyphagia and weight loss. There is peripheral vascular insufficiency, provoking scarring, and physiological changes that decrease the immune capacity, increasing the susceptibility to infections. ${ }^{1}$ In addition, some microorganisms become more virulent in a high glucose environment. Another mechanism that may lead to an increase in the prevalence of infections in diabetic patients is an elevated adhesion of microorganisms to the diabetic cells. ${ }^{2}$ Early diagnosis is essential to avoid problems caused by this syndrome. The diabetic patient's mucosa is subject to even greater stress than the healthy patient's one when occlusal forces, tissues trauma, maladaptation of the prosthesis' bases, surface loading of denture base materials, and dimensional changes occur. ${ }^{3}$ However, in clinical practice, oral lesions due to the use of iatrogenic prostheses and poor patient orientation by the dental surgeon regarding use and hygiene are also observed ${ }^{4}$ Thus, the objective of the present study is to verify which are the main oral alterations in users of complete dentures associated with Diabetes Mellitus, through literature review.

\section{Proposition}

The purpose of this study is to perform a review of the literature on oral manifestations present in diabetic patients using total prosthesis.

\section{Discussion}

Studies that relate the oral manifestations caused by Diabetes Mellitus using complete dental prosthesis, demonstrate a concern of researchers at a global level, because Diabetes Mellitus can trigger systemic and oral problems. In addition, because of the complexity of the management of blood glucose control, it is necessary to periodically monitor these patients in order to reduce their complications. ${ }^{5,3}$

The dentist is a professional able to identify the oral manifestations and to alert the patient users of complete dentures caused by Diabetes Mellitus. ${ }^{1}$ The most common and most prevalent oral problem is
Prosthetic Stomatitis. ${ }^{6}$ Several mechanisms are used to explain the increase in susceptibility of the disease, such as changes in immune response, vascularization, and age..$^{7-9}$ However, its etiology is controversial, and it is believed to be multifactorial. It may be related mainly to local factors, such as poor oral health of patients with complete dentures, trauma, allergic reactions and Candida infections. ${ }^{10}$

The absence of metabolic control may be related to the presence of fungal infections, such as Candida. ${ }^{11}$ However, the higher production of colonies by Candida albicans is higher in these patients. The higher production of Candida albicans colonies, such as Candida albicans, Candida spp., Candida tropicalis and Candida glabrata $^{12}$ (Sanitá et al, Fornari et al, Silva et al). As with resilient silicone based prostheses, they exhibit increased Candida growth in diabetic patients. ${ }^{13}$

Bianch et al. Falcão et al. state that what predisposes the patients is not Diabetes Mellitus, but the use of dental prosthesis and poor oral hygiene. The main types of lesions affecting the oral cavity are derived from poorly adapted or poorly sanitized dental prostheses, which could be avoided if, after installation of the prosthesis, the professional made adequate adjustments, guided hygiene and performed more severe periodic follow up. ${ }^{14}$

Decreased salivary flow, increased acidity and salivary viscosity characterize Xerostomia. The signs and symptoms of the patients in the clinical examination are: the mucosa has a dry appearance, the patients report burning in the tongue, erythema, tasting disorders, phonation, lack of saliva in the buccal floor, discontinuation of the traumatic ulcer, which can aggravate a lot certain oral conditions. ${ }^{1,15-17}$ The duration of the Diabetes Mellitus, the age and sex of the patient did not affect negatively rates of salivary flow. (Chavez et al.). An alternative treatment are the salivary substitutes, which may be efficient in reducing the amount of yeast. Lima et al. ${ }^{18}$ Sousa et al. ${ }^{19}$ Paiva et al. ${ }^{20}$ argue that there are no significant differences in salivary flow, retention of dental prostheses or oral lesions in diabetic patients.

Diabetes Mellitus is considered a serious public health problem, since it is a systemic disease, it has influence in every organism, including in the oral cavity, therefore, it is important that the dental 
surgeon be part of the multiprofessional team, playing an important role in the promotion and maintenance well-being and quality of life of diabetic patients. ${ }^{21,22}$

\section{Conclusion}

The results of the present review allow us to conclude that the diabetic patient with complete dentures has greater predispositions for oral manifestations such as: Prosthetic Stomatitis, fungal infection by Candida, and Xerostomia. However, a well manufactured, installed, and adapted prosthesis together with good oral hygiene of the patient, as well as adequate control of the chronic disease are determinant so as not to aggravate the aforementioned conditions. Nevertheless, further randomized and controlled trials are needed to provide more conclusive answers on oral manifestations in diabetic users of complete dentures.

\section{Acknowledgments}

None.

\section{Conflicts of interests}

The authors of this manuscript have no competing interests.

\section{References}

1. Sousa RR, Castro RD, Monteiro CH, et al. O Pacontane odontológico portador de diabetes mellitus: Uma revisão de literature. Pesq Bras Odontoped Clin Integr. 2003;3(2):71-77.

2. Silva MCA, Alena AN, Chavasco KJ, et al. Erythematous Oral Candiceis in patients with controlled type II diabetes mellitus and complete dentures. Mycopathologia. 2010;169:215-223.

3. Ganapathy DM, Joseph S, Ariga P, et al. Evaluation of the influence of blood glucose level on oral candidal colonization in complete denture wearers with Type-II Diabetes Mellitus: An in vivo study. Dent Res $J$ (Isfahan) .2013;10(1):87-92.

4. Goiato MC, Castelleoni L, Santos DM, et al. Lesões Orais Provocadas Pelo Uso de Próteses Removíveis. Pesq Bras Odontoped Clin Integr. 2005;5(1):85-90.

5. Cantanhede, Kátia Maria, Liana Linhares. O idoso portador de diabetes mellitus sob a perspectiva odontológica. Rev Bras Clin Med. 2013;11(2):178-182.

6. Serrano GJ, Serrano J, Pintor RML, et al. Prevalence of oral mucosal disorders in diabetes mellitus patients compared with a control group. Journal of Diabetes Research. 2016.

7. Bajaj S, Prasad S, Gupta A, et al. Indian journal of endocrinology and metabolism. Chávez Oral Surgery Oral Pathology. 2012;91 (2):163-177.
8. Hofling JF, Barros ML, Alves ACBA, et al. Colonização bucal por espécies de candida. Passo fundo. 2004;9(1):16-21.

9. Loster JE, Wieczorek A, Loster B. Correlation between age and gender in Candida species of infections of complete denture wearers: a retrospective analysis. Clin Interv Aging. 2016;11:1707-1714.

10. Oliveira RC, Brum SC, Oliveira RS, et al. Estometus clicnic relativity is a prototype. International Journal of Denstistry. 2007;6(2):51-54.

11. Lotfi-Kamran MH, Jafari AA, Tafti AF, et al. Candida colonization on the denture of diabetic and non-diabetic patients. Dent Res $J$ (Isfahan). 2009;6(1):23-27.

12. Fornari G, Herkert PF, Redivo DDB, et al. Epidemiologia da colonização de leveduras candidas da cavidade bacientes diabéticos. Sabios: Rev Saúde e Biol. 2013;8(2):1-6.

13. Mantri SS, Parkhedkar RD, Mantri SP. Candida colonisation and the efficacy of chlorhexidine gluconate on soft silicone-lined dentures of diabetic and non-diabetic patients. Gerodontology. 2013;30:288-295.

14. Neto MM, Danesi CC, Unfer DT. Candídiase Bucal. Saúde. 2005;31:1626.

15. Al-Dwairi, Lynch. Xerostomia in complete denture wearers: prevalence, clinical findings and impact on oral functions. Gerodontology. 2014;31(1):49-55.

16. Yamashita JM, Moura-GPG, Capelaria MM. Rev Odontol UNESP. 2013;42(3):211-220.

17. Silva IJO, Almeida ARP, Falcão NC, et al. Hipossalivação. Revista Bahiana de Odontologia. 2016;7(2):140-146.

18. Lima DC, Nakata GC, Balducci I, et al. Oral manifestations of diabetes mellitus in complete denture wearers. The Journal of Prosthetic Dentistry. 2008;99(1):60-65.

19. Sousa MGM, Costa ALL, Roncalli AG. This is a form of diabetes mental health problems. Brazilian Journal of Otorhinolaryngology. 2011;77(2):145-152.

20. Paiva MDEB, Araujo AMM, Piuvezam MR, et al. Fluxo salivar e concentraco do Ferté de Crescimento Epidérmico (EGF) is a pacient diabetic tipo 2. Odontol Clin-Clent Recife. 2010;9(3):235-237.

21. Alves $\mathrm{C}$, Brandão $\mathrm{M}$, Andion $\mathrm{J}$, et al. Atendimento odontológico do paciente com diabetes melito: recomendações para a prática clínica. Rev Ci méd biol. 2006;5(2):97-110.

22. Radović K, Ilić J, Roganović J, et al. Denture stomatitis and salivary vascular endothelial growth factor in full denture wearers with type 2 diabetes. The Journal of Prosthetic Dentistry. 2014;111(5):373-379. 